\title{
IMPLEMENTATION OF TOTAL QUALITY MANAGEMENT ON CON- STRUCTION OF ASSYRIAN LIBRARY PROJECT
}

\author{
Hiba. H. Alwan ${ }^{1}$ (1D) Ammar. A. Mohammed Ali $^{2}$ and Yazen. N. Mahmood ${ }^{3}$ \\ ${ }^{1}$ Assistant Lecturer Petroleum Engineering Department, College of Engineering, Knowledge University, Kurdistan Region- \\ Iraq \\ ${ }^{2}$ Ninewa Education Directorate, Ministry of Education, Ninewa - Iraq \\ ${ }^{3}$ Assistant Lecturer, Management Department, College of Management and Financial Science, Knowledge University, Kur- \\ distan region- Iraq
}

\section{ABSTRACT}

The purpose of this research is to evaluate the work of construction of an Assyrian library affiliated with the University of Mosul, which was based on conditions and procedures for quality control on both the administration and the engineering aspects taking in consideration the stages of the projects during the construction. When applying the quality requirements to the project in terms of achievement and integration, it found that there was a delay in the time of site implementation, in addition to the fact that the actual data with presumed. As well as the lack of high-quality data on the machines used for construction

Received 20 March 2021

Accepted 5 April 2021

Published 30 April 2021

Corresponding Author

Hiba. H. Alwan, hiba.alwan@knu.e

du.iq

DOI $10.29121 /$

granthaalayah.v9.i4.2021.3803

Funding: This research received no specific grant from any funding agency in the public, commercial, or not-for-profit sectors.

Copyright: (C) 2021 The Author(s). This is an open access article distributed under the terms of the Creative Commons Attribution License, which permits unrestricted use, distribution, and reproduction in any medium, provided the original author and source are credited. by the company. In general, however, some criteria have yielded satisfactory results in terms of on-site work.

Keywords: Library Quality Management, Assyrian Library, TQM of Libraries, Quality Assurance, Quality Projects

\section{INTRODUCTION}

For building special libraries for sciences and cultures, it may focusing on the quality factors in detail during construction, using equipment, and even labor by applying the TQM.

Because of the technological innovations of modern electronic magazines have made communication with this type of libraries a few. Therefore, the process of quality management of this type of libraries requires expansion or interference between the administration and engineering aspects to make such a kind of libraries attractive for knowledge.

Quality is the basic philosophy and requirement of library profession and all libraries strive to deliver the highest quality of service. Quality is about expectations 
of functional performance. A quality service is one that fully meets expectations and requirements of the users. If a library provides right information to right user at right time and in required form, then it is maintaining quality Sharma (2001).

The National Accreditation and Assessment Council. NAAC conducts audits and inspections on the quality of service provided by educational institutions, including library service. Grants are linked to the outcomes of these assessments. In light of this, academic libraries must develop systems, philosophies, and strategies for managing quality. The primary purpose of an academic library is to support the teaching, research, and other academic programs of its parent organization. An academic library is part of a service organization which delivers products personally to the customer, Singh (2013). Quality is a degree of excellence for customer satisfaction through product or by service. Quality is often used synonymously with excellence, Sathe (2015).

According to Lawrence (2000), quality management is the aspect of the overall management function that determines and implements the quality policy, requires the commitment of top management including strategic planning, allocation of resources and other systematic activities for quality, such as quality planning, operations and evaluations. Therefore, quality management consists of four main constructs - quality planning, quality control, quality assurance, and quality improvement, whereby it focuses not only on product/service quality, but also on how to achieve it, Taib and Warokka (2012).

(TQM) which means a system of running the affairs of an institution or organization such that all the aspects of the organization and appropriate resources are provided and utilized towards actualizing the goal of organization, Ogunlana et al. (2008).

Engineering Projects Management is an integrated scientific system, as it includes many different processes and stages. such as: The project framework is the planning and formulation of the objectives of the project, Manage the project domain, Manage the time needed to manage the project and implement its stages until delivery, cost management and budget determination., Quality management and achieving the highest quality and conformity to the specifications on which the project will be, Human resources management and selection of trained manpower to lead the project professionally to the ability to distribute tasks within the project, Risk management, cost and ability to properly link project departments, Management of estates and how to communicate between departments to meet the needs of the project in the right manner and in the specified dead, Communications and Stakeholders Management, Management of integration and communication between employees and departments and control of work and all phases of the project and until the completion and delivery of all this is one of the tasks of project management and essentials for any project. 


\section{MATERIALS AND METHODS}

The sample is taken for this research is the Assyrian General Library located at the University of Mosul to study the quality of the work of this library. The type of sample was Surveying the construction company who was build this library. The survey was focusing on the work of engineers and company services.

\subsection{THE PROPOSED METHODOLOGY}

This section explains the proposed research, including description of the data, Data characterization, and data entry.

\subsubsection{DESCRIPTION OF THE DATA}

Data description is expressed in the following paragraphs:

1. Project Name: Establishment of Assyrian Library and Cuneiform Studies Institute (under construction

2. Project area: 50000 square meters

3. Implementation date: 2002 - (stopped 2003 and started in 2005 - Work continues

4. Description of the project data:

The Table 1 indicates the description of the Assyrian Library project data, noting that all the data are not available because the project is still under implementation, and the absence of the estimated cost is due to the specificity of this project, which has been halted for several years, but has been reinstated.

\begin{tabular}{lll}
\hline \multicolumn{2}{l}{ Table 1 Data Description of Assyrians Library } \\
\hline Stage & First & Second \\
\hline Executive Year & 2005 & 2011 \\
\hline The Executing Agency & Al-Mansour Company & Al-Mansour Company \\
The Beneficiary & University & University \\
\hline The Estimated Cost & 120 Billion \& 10Million IqD & 157 Billion \& 30 Million IqD \\
\hline & & \\
\hline Actual Cost & 117 Billion \& 4 Million IqD & Underway \\
\hline $\begin{array}{l}\text { Duration } \\
\text { Actual Duration }\end{array}$ & 2618 Days & 1198 Days \\
\hline
\end{tabular}

\subsubsection{DATA CHARACTERIZATION}

The most dimensions will be based on an agreement between the researchers, as well as their compatibility with the field of study and the possibility of quantifying them: 
1. The accuracy of the information means the degree of validity of the information as the information is material and meaningful and clear, and the information is accurate when it is error-free. In general, the accuracy of the data affects the accuracy of the information that Produced from the information system.

2. Consistency: Matching is important when there is a difference in data, especially when a set of data or databases is compared, and consistency is confirmed by the relevant dimensions, Askham and Others (2013).

3. Reliability: Confidence is an important factor. The higher the quality of the data, the higher the confidence of the beneficiaries. The confidence in the data indicates that the user is safe and the desire to rely on the information. Confidence is dynamic. To another because they affect the positions of beneficiaries.

4. Timely: Successful decision-making depends on the arrival of the required information when it is actually needed without delay or submission. The data on which the information is based must be integrated and consistent. When timely and inconsistent information is obtained, it will result in Negative results because the data must be up-to-date and easy to access and available when needed because it means the ability to provide reliable and reliable information to make the right decision in a timely manner.

5. Valid: Indicates the possibility of using the information which may coincide with the update to it, the validity means the possibility of use in the sense did not occur in a way that invalidates its validity.

From the definitions that were putting forward, it seems that TQM can be defined as a management system that involves all elements of personnel in the environment of a company, both the goods sector (good product) and the service sector (services) aimed to improve the quality, efficiency and effectiveness production in industrial environments as well as other institutions Norman (2019).

\subsubsection{DATA ENTRY}

The relevant studies indicate that there are two inputs to measure:

Firstly. Qualitative input: This approach is based on data quality attitudes and is certainly constructed from one person to another. These positions can be obtained by questionnaire or interviews as in the study.

Second. Quantitative input: This approach is based on mathematical models of measurement. It measures some dimensions of data quality. Refers to these dimensions:

1. Accuracy: Calculated by the following equation:

$A=\frac{1}{(k-1)} \sum_{i=1}^{k-1}[r(i)](1)$

Variable (A) represents precision.

The variable ( $\mathrm{r}(\mathrm{i})$ ) represents the relative revision, calculated by the following equation: 
$\mathrm{r}(\mathrm{i})=\frac{x_{i}-x_{k}}{x_{k}}(2)$

(Xi) represents the temporary state.

(Xk) represents the current or executed state.

2. Time: Calculated by the following equation:

$\mathrm{T}=\frac{T_{m}-T_{n o m}}{T_{m}}(3)$

The variable $(\mathrm{T})$ represents the total time of the project.

The variable $(\mathrm{Tm})$ represents the time period during which the project was executed.

The variable (Tnom) represents the time period for completion of the project.

3. Validity: The validity is calculated according to the following equation Askham and Others (2013)

Validity $=$ (the sum of the data collection of the metadata) / number (4)

4. Matching: Matching is calculated according to the following formula Matching $=($ Accuracy + Validity + Time $) / 3$ (5)

\section{RESULTS AND DISCUSSIONS}

It should be noted that the quantitative approach was adopted because it can be applied in dimensions of accuracy, time, validity, conformity and with respect to confidence, it will be measured based on official documents.

In the Table 2 , we cannot calculate the quality of data for all stages of the Assyrian Library because the project is not completed. But note that the first phase of the project was containing good indicators, indicating that there is a clear interest in the quality of data by the resident engineer on the project.

Table 2 Quality of the data of the Library

\begin{tabular}{|c|c|c|c|c|c|c|}
\hline $\begin{array}{l}\text { Dimension } \\
- \\
\text { Stage }\end{array}$ & $\begin{array}{l}\text { Accu- } \\
\text { racy }\end{array}$ & Time & $\begin{array}{l}\text { Reliabil- } \\
\text { ity }\end{array}$ & $\begin{array}{l}\text { Valid- } \\
\text { ity }\end{array}$ & $\begin{array}{l}\text { Consis- } \\
\text { tency }\end{array}$ & $\begin{array}{l}\text { Total Values of each } \\
\text { stage }\end{array}$ \\
\hline First Stage & $100 \%$ & $100 \%$ & $100 \%$ & $87 \%$ & $95 \%$ & $96 \%$ \\
\hline Second Stage & None & None & $100 \%$ & None & None & None \\
\hline
\end{tabular}

The following paragraph will illustrate the measurement of integration as follows:

1. Measuring integration based on the project itself, The Table 3 indicates that there is a weakness in dealing with data types in particular, as well as a lack of access and discovery and this indicates a weak performance of the resident engineer in terms of access to information related to the project.

2. Integrating the information of the executing companies. The Table 4 shows that there is only a weakness in the quality of the mechanisms, equipment and expertise. However, there is a clear interest from the resident engineer on the project to integrate the information with the project executing company, which may reduce the impact of the poor performance of the resident engineer in obtaining the project information. 


\begin{tabular}{|c|c|c|c|c|c|c|c|c|}
\hline $\begin{array}{l}\text { Stage } \\
- \\
\text { State }\end{array}$ & Access & Discover & Category & Integrat & Deliveı & $\begin{array}{l}\text { Developr } \\
\text { and } \\
\text { Man- } \\
\text { age- } \\
\text { ment }\end{array}$ & $\begin{array}{l}\text { Audit, } \\
\text { control } \\
\text { and } \\
\text { report- } \\
\text { ing }\end{array}$ & $\begin{array}{l}\text { Total } \\
\text { assess- } \\
\text { ment of } \\
\text { the State }\end{array}$ \\
\hline $\begin{array}{l}\text { Dealing } \\
\text { with } \\
\text { data }\end{array}$ & 1 & 1 & 1 & 1 & 1 & 1 & 1 & $100 \%$ \\
\hline Site & 1 & 0 & 1 & 1 & 1 & 1 & 1 & $85 \%$ \\
\hline Time & 0 & 0 & 1 & 1 & 1 & 1 & 1 & $71 \%$ \\
\hline $\begin{array}{l}\text { Types } \\
\text { of data }\end{array}$ & 0 & 0 & 0 & 0 & 1 & 1 & 1 & $42 \%$ \\
\hline Use & 1 & 1 & 1 & 1 & 1 & 1 & 1 & $100 \%$ \\
\hline $\begin{array}{l}\text { Total } \\
\text { grade } \\
\text { estima- } \\
\text { tion }\end{array}$ & $60 \%$ & $40 \%$ & $80 \%$ & $80 \%$ & $100 \%$ & $100 \%$ & $100 \%$ & $79 \%$ \\
\hline
\end{tabular}

Where,

(0) Represent ( not valid)

(1) Represent (valid)

\begin{tabular}{ll}
\hline Table 4 Result data for the Library project companies \\
\hline Company Data & Result \\
\hline Suppliers, processors & 1 \\
Quality of machinery, equipment and expertise & 0 \\
Secondary Contracting & 1 \\
The company's level of presence & 1 \\
Performance of the company & 1 \\
Financial, legal and administrative data & 1 \\
Total estimate & $83 \%$ \\
\hline
\end{tabular}

Where,

(0) Represent ( not valid)

(1) Represent (valid)

\section{CONCLUSIONS AND RECOMMENDATIONS}

The findings of the study referred to a number of conclusions which we include as follows:

1. The data is poorly matched to the organization surveyed in general and by medium proportions when compared to the other dimensions. This is due to the Department's interest in the official aspects only, without attention to informal communication to ascertain the ability of the executing company.

2. The data quality component appears due to the availability of specific standards that represent quality indicators, which provides project managers with the reduction of deviations due to prior measurements. 
3. The field does not rely on specific data description criteria, and this is due to the availability of data with the context to display.

4. Data and information are handled with the available procedures, according to the management that will enhance the performance of the project where the level of integration has decreased. This may be due to the knowledge of the project owners, (Engineering), which does not enhance the handling according to the visions of management in spite of the convergence of theoretical management and engineering. In addition, the field in the standards that assess the integration of the company, but it is not exploited in a way that will benefit of the field because of poor dependence on some projects.

5. Weak vision of the data required for the project. Because, the data is not updated to include other indicators through which ascertain ability of the company to complete the project that assigned to it.

6. The absence of a database of companies that working in the university, which emerged as a company working for more than one project at the university. Only the data that is related to the resident engineer.

\section{REFERENCES}

Askham, N. . O., \& Others. (2013). The Six Primary Dimension for Data Quality Assessment Defining Data Quality Dimensions. UK. Retrieved from www.damauk.org

Norman, E. (2019). The Implementation of Total Quality Management at MAN 2 Bogor. Jurnal Manajemen, 10(1), 93-93. Retrieved from https://dx.doi.org/10.32832/jm-uika.v10i1 .1564 10.32832/jm-uika.v10i1.1564

Ogunlana, E., Kunle, A., \& Isiak, O. (2008). Quality Assurance in subject Librarian Services and Library Magament. In Conference Paper.

Sathe, D. V. S. (2015). TOTAL QUALITY MANAGEMENT IN LIBRARIES. "Knowledge Librarian"An International Peer Reviewed Bilingual E-Journal of Library And Information Science, 2(1), 130-150.

Sharma. (2001). Total Quality Management and its Application in Library and Information Centers. In and others (Ed.), .

Singh, K. (2013). Total Quality Management To Library And Information Services In Indian Open Universities. J.T.University, Journal of Business Management \& Social Sciences Research, 2(6).

Taib, A. C. A., \& Warokka. (2012). Haim hilman Abdullah, The Library's Quality Management System and Quality Assurance in Higher Education: A Lesson from Southeast Emerging Educational Hub. College of Business - UUM. 